Jurnal The Messenger, Vol. 10, No. 1, January 2018, pp. 14-23

P-ISSN: 2086-1559, E-ISSN: 2527-2810

DOI: $10.26623 /$ themessenger.v10i1.604

\title{
The Representation of Democracy in Islamic News Sites VOA-Islam and ArRahmah
}

\section{Representasi Demokrasi dalam Situs Berita Islam VOA-Islam dan ArRahmah}

\author{
Detta Rahmawan $^{1}$, Justito Adiprasetio ${ }^{1}$, Preciosa Alnashava Janitra ${ }^{1}$ \\ ${ }^{1}$ Faculty of Communication Sciences, Universitas Padjadjaran, Jl. Raya Bandung \\ Sumedang KM 21, Jatinangor 45363, Indonesia \\ *Corresponding author, e-mail: detta@unpad.ac.id
}

\begin{abstract}
Various groups with Islamic ideology in Indonesia are emerging and often promoting the idea of Islamic Law to replace democratic concept. Some of these groups use various websites to deliver their ideology to the public and as a form of resistance to the mainstream news. This study uses framing analysis to reveal how Islamic news websites such as VOA-Islam and ArRahmah, portray the concept of democracy unilaterally, according to what they believe. Throug the analysis results that have been done, it is found that the sites frequently claim that democracy is fail system, because democracy is "expensive" system, creates political oligarchy, and against the teachings of Qur'an. These Islamic news websites also frequent;y used information from anti-democratic organization members such as HTI (Hizbut-Tahrir Indonesia), as their primary sources. By contrasting the concept of democracy with Islamic values, this group offered narration that did not lead to healthy and productive discussion.
\end{abstract}

Keywords: Democracy, Islamic News Websites, Islamism.

\begin{abstract}
Abstrak
Berbagai kelompok dengan ideologi Islamisme di Indonesia mulai muncul dan kerap mempromosikan gagasan mengenai hukum Islam untuk menggantikan konsep demokrasi. Beberapa kelompok ini menggunakan beragam situs untuk menyebarkan ideologi mereka ke publik dan sebagai bentuk perlawanan terhadap berita arus utama. Penelitian ini menggunakan analisis framing untuk mengungkapkan bagaimana situs berita Islam seperti VOA-Islam dan ArRahmah, menggambarkan konsep demokrasi secara sepihak, sesuai dengan apa yang mereka yakini. Melalui hasil analisis yang telah dilakukan, terlihat bahwa situs-situs ini kerap mengklaim bahwa demokrasi adalah sistem yang gagal, karena demokrasi adalah sistem yang "mahal", menciptakan oligarki politik, dan bertentangan dengan ajaran Al-Quran. Situs-situs berita Islam ini juga sering menggunakan informasi dari anggota organisasi anti-demokrasi seperti HTI (Hizbut Tahrir Indonesia), sebagai sumber utama mereka. Dengan membenturkan konsep demokrasi dengan nilai-nilai Islam, kelompok ini menawarkan narasi yang tidak mengarah pada diskusi yang sehat dan produktif.
\end{abstract}

Kata Kunci: Demokrasi, Situs Berita Islam, Islamisme.

Copyright (C) 2018 Universitas Semarang. All rights reserved.

\section{Introduction}

As a country that currently has the largest Moslem population in the world, Indonesia has been regarded as one of the most stable democratic countries with wellregarded press freedom and dynamic civil society. But in recent years, various political parties and groups as well as community organizations that embrace the ideology of

Article History: Received October 01, 2017; Revised January 16, 2018; Accepted January 25, 2018; Published January 31, 2018 
Islamism tend to be radical arise and often promote the idea of Islamic law to replace the secular-democratic political system in Indonesia. This phenomenon can also be seen in the report from HRW (Human Rights Watch) which states that since Soeharto's fall, conservative Islamic groups have grown in political influence, one of them because political parties and some civil society groups that have radical Islamic ideology operate in the outside of the political system have grown in size, number, and sophistication (Human Rights Watch, 2013: 14).

In that context, some Islamic groups in Indonesia use various websites as media to support their political agenda, propagate their ideology to the public, and as the form of resistance to "mainstream" news. They often use provocative statements and languages to build narratives and ideas of democracy in accordance with what they believe, i.e bad concept and contrary to the teachings of Islam. This study tries to analyze how ArRahmah and VOA-Islam, for examples of Islamism news website in Indonesia, describe democracy as "fail ideology" and not beneficial to Indonesian citizens while emphasizing the importance of applying Islamic law in kaffah way in Indonesia.

Islamism in Indonesia

There are various studies on the interpretation of Islam as religion and as political movement. In academic discourse some scientists have tried to "categorize" Islam as religion, as ideology or as political movement, with various labels such as; fundamentalist Islam, radical Islam, liberal Islam, moderate Islam, traditional Islam, and so on (Brown, 2010: 333). However, Brown also reminds that scientists who study Islam must be fully aware that all the labels embedded in Islam have biased tendency, and generalize the complex problems and differences in Islam, he reminded that; "[ the concept] of Islam ... is inherently diverse" (2010: 333). The labels embedded on Islam are often problematic, especially in the "western" world because some of them are related to other notoriously negative idea such as "terrorism".

Therefore, in this study we choose the word "Islamism" which specifically refers to the ideology or political movement of Islam that needs to be released from terrorism in the name of Islam (Azzam, 2006: 1129). Besides, from historical and political perspective, one important concept about Islamism is about the importance of the application of Islamic Law (Shari'a). It can be said that the main ideological assumption of Islamism is contrary to the idea of democracy developed and promoted by many countries in the West, about the crucial role of "people sovereignty". As Bassam Tibi stated in the book "Islam and Islamism", that the crisis of democracy in the Arab world is seen as the result of the unused of Islamic law strictly and thoroughly (Tibi, 2016: 3).

The political context of Islamism in Indonesia can be found for example from Mujani \& Liddle study on the democratization process in Indonesia after the fall of Suharto's authoritarian regime in 1999. They wrote that most political parties participating in three national parliamentary elections (1999, 2004, and 2009) applied the secular democracy ideology even though the majority of its citizens are Moslem (2009: 576). It is important to note that in their study the term "secular" refers specifically to political systems that are not exclusively allied with or contrary to particular religion, but secular meant in the Indonesian context is to refer to the ideology of "Pancasila" and the belief in one God as the first principle in Pancasila (Mujani \& Liddle, 2009: 577). Pancasila (as secular political principle) has been implemented by many Indonesian political parties. However, some parties also openly stated that they embraced Islam as an ideology and political platform, such as the Development United Party (DUP) and Prosperous Justice Party (PJP) (Mujani \& Liddle, 2009).

Jurnal The Messenger, Vol. 10, No. 1, January 2018, pp. 14-23 
In addition, other Islamic groups outside the official political system have also grown in large numbers. The examples of Islamic mass groups or organizations are; Forum Umat Islam (FUI), Forum Komunikasi Muslim Indonesia (Forkami), Front Pembela Islam (FPI), Hizbut Tahrir Indonesia (HTI), dan Gerakan Islam Reformis (Garis) (Human Rights Watch, 2013). Nevertheless, of various researches that have been done on Islamism, it is said that the ideology of Islamism in Indonesia can not necessarily be attached to certain political organizations or parties.

Among these groups, there are two very prominent groups in Indonesia, one of which is Hizbut Tahrir Indonesia or HTI which is famous for its rejection against democracy and its desire to "revive the Islamic Khilafah in Indonesia" (Nawab \& Osman, 2010: 603). The next group, Front Pembela Islam atau FPI is famous for its leader Rizieq Syihab who likes to issue controversial statements related to government, and often this group uses violence to impose "amar ma'ruf nahi munkar" (enjoining the right and forbidding the wrong) (Bamualim, 2011: 270). The existence of these groups is largely apparent when they conduct public demonstrations against things they find inappropriate; The "Miss World" beauty contest (Roberts, 2013), Valentine's Day celebration, (The Daily Star, 2013, The Telegraph, 2013), to a series of Islamic defending actions related to case of religious defamation by former Jakarta governor, Ahok (Kami, 2017). In general, it can be said that organizations such as HTI and IDF often appear in Indonesian mainstream media with issues that tend to be negative. Therefore, these groups often complained that their image had been described by mainstream media unfairly (Hartawan, 2012, Budiasa, 2017: 36).

Islamism News Website in Indonesia

Currently it can be said that there is rapid development of Internet penetration and digial media users in Indonesia. Especially for the younger generation, many of them are currently increasingly turning to online media, and begin to leave the printing media or other conventional media. This rapid development is also supported by the increasingly affordable price of Smartphones, leading to more and more personalized mobile information consumption (Vollmer, 2017; We Are Social, 2017: 34). Various contents and information that before the Internet era are difficult to consume now can spread widely, easily and quickly. With the existence of digital media, information flows incessantly, and used by many parties, one of them is by Islamists in Indonesia.

It can be said that the ideology of Islamism which tends to be "hard" in Indonesia does not have place in the mainstream mass media. Nevertheless, research mentioned that Islamism spreads rapidly through religious meetings where they can meet directly and share material, as well as through various online media. Jennifer Yang Hui had studied the Islamic news sites in Indonesia and emphasized how these sites provided information about "Islamic perspectives and agenda in post-Suharto democracy". He noted that some of the sites he analyzed contained provocative content that could be used as propaganda media of extremist ideology. However, he also noted that "many participants/visitors [of the sites] tend to pay more attention to practical problems than the desire to engage in the acts of terrorism" (Hui, 2010: 186).

Compared to the mainstream media, Islamism news websites in Indonesia have their own unique characteristics. Of course in general this site serves as news portal to disseminate information about Islamism in Indonesia both in political and non-political context. However, it is evident that these sites also often pay attention to matters related to Moslems outside Indonesia and spread "anti-Jewish sentiment" (Hui, 2010: 174). Other studies also show similarly thing that these sites often show the condition of the 
followers of Islam in countries other than Indonesia, but of course the various news are curated strictly, so that many of the news shown are about Islam related to Jihad, the war againsts the countries and ideologies categorized as "enemies of Islam", as well as other Islamic-related conflicts, most of which occur in Middle East countries. In addition, some in-depth information about the application of Islamic law in everyday life is also one of the information that is often consumed by the Islamists.

\section{Methodology}

The mass media always have the power to disseminate content containing information that may affect public opinion on certain issues. The emergence of various types of mass media such as newspapers, radio, and television has made the media an important source of information for the community. However, scientists believe that news is "structured process", and always be "representation from particular point of view" (Fowler, 1991: 209). This study uses Framing analysis to see how the narration in a media is built through protrusion of certain texts (Eriyanto, 2012: 252).

News is built through media texts that are "created and updated through various language usages" (Matheson, 2005: 2). The selection of various texts in the media can show how a reality is built, and what messages are consistently displayed. Framing analysis is often used to examine conventional media texts (Adhitama, 2016: 28) as well as digital media or social media (Aminuddin, 2017: 167). The critical paradigm we use means the text must also be analyzed not only through discourse analysis arranged linguistically but also through an understanding of social and political theory which relevant to express power and ideology within the text (Fairclough, 1989: 81).

It can be said that the "powerful groups" referred to in this study do not refer to the ruling or capitalist class as written in Matheson's books, but in this context, these groups refer to Islamic groups that show their power and authority through the sites of Islamism like ArRahmah and VOA-Islam because they do not have power to do so in mainstream media. This study explores what the Islamist groups communicate in the existing text and for whose interests the text exists (MacDonald, 2003: 22).

We identified the "main themes and arguments" in the text (Tonkiss, 2006: 378), examined the choice of words used to build reality, and looked closely about the constructed "labelling" (Fowler, 1991: 94). Then, patterns indicating that there was particular idea that continues to be built in certain way could be found.

\section{Result and Discussion}

Internet penetration according to Bunt in various Moslem countries such as Indonesia provides the way for what he calls an "Islamic information revolution" which also has significant influence over the use of the Internet by various Islamic movements online, or "cyber Islamic activism". Internet penetration and digital media have provided space previously unavailable through traditional media or mainstream media (Bunt, 2006: 153-161).

This space is a new arena that can be used for various consolidated movements and enhancement of communication networks among them or among equally ideological (Islamist) parties as well as among them and Moslems outside their circles in general. These groups build and manage a virtual community formed through ideological similarities across physical boundaries. Through these sites local and global Islamic identities are established and communicated within the community (Whine, 1999: 130).

Jurnal The Messenger, Vol. 10, No. 1, January 2018, pp. 14-23 
The Internet and digital media are also seen to play the key role and to become new tool for Islamists to spread collective identities, to organize collective action, to create space that is no longer restricted to exchange ideas, and to build networks. But of course the use of the internet associated with the Islamist movement can not be seen as a single phenomenon. Just like the Islamic ideology that has its own distinct branches and peculiarities in every country, the Islamist movement will also always be related to the existing socio-cultural conditions, and also see the technological infrastructure factors available in the country (Iqbal, 2017: 19).

This study is focused on several articles from VOA-Islam and ArRahmah.com which discuss democracy in Indonesian context (list of articles attached). ArRahmah and VOA-Islam are examples of two popular Islamic news sites that offer news and articles related to Islam that are mostly written in Indonesian. According to Alexa.com, a company that is often used to observe the ranking or performance of a site, the top search queries, or some keywords that are often used for this site are; "Islamic world news", "Islamic news" and so on. The public of these two sites in general are; "Men who are in the age range of 25-34, have children, do not have college education and surf the site from home" (Alexa, n.d.).

VOA-Islam, according to information on its website, operates since June 1, 2009. The purpose of establishing this site is because they think Moslems become marginalized and often get negative labels such as terrorists, fundamentalists, etc. Therefore the VOA-Islam site becomes a site that voices various Islamic movements and news. In its website there is complete description about the author editor of VOAIslam. But when it was traced through the Internet, there was not information from the owner of the site called Sabrun Jamil. This site is included in one of the sites that has ever been blocked by Kominfo because many of its articles are related to SARA issues (Prihadi, 2017).

Arrahmah.com is an Islamic news site owned by Muhammad Jibriel. His name had ever listed into one of the parties associated with the bombing case of JW Marriott and Ritz-Carlton Hotels in Mega Kuningan, Jakarta, 2009. He was hit by cases of document forgery and allegations of information concealment. As described in Kompas.com, Jibriel had been proven to hide information on the whereabouts of Noordin M Top and Saefudin Zuhri and was also guilty on passport misuse case. After undergoing the trial he was sentenced to five years in prison, but in November 2012, after serving a three-year sentence Jibriel was released on parole (Yusuf, 2016).

Arrahmah.com, according to one study, is also part of Arrahmah community network which often promotes the ideology of jihad and salafis (Iqbal, 2017: 78). Until now, this community still exists with various donations of money given by the readers. This site has ever been included in one of the sites blocked by Kominfo because it is considered to have content containing radicalism according to the recommendation of Badan Nasional Penanggulangan Teroris (BNPT). Nevertheless, in several media interviews, Jibriel has always insisted that his site is not radical site, but only broadcast news and information about the Islamic struggle that is still packed in Journalistic rules (Abba, 2015).

In an article entitled "Omongkosong Demokrasi" (12/01/17) VOA-Islam presented an article by HTI Activist Firdaus Bayu explaining some cases that occurred in Indonesia, which, according to him, demonstrated the "lies" of democracy, the "inconsistency" of the democracy process with the will of the "majority" of the Indonesian people, and the call to return to Islam. In this article, cases such as fuel price 
hikes, Freeport cases and religious defamation cases conducted by former Jakarta governor Basuki Tjahaja Purnama or often called Ahok were served as examples of how the government always tries to manipulate people under the pretext of democracy. Then at the end of his article, Firdaus Bayu reminded that democracy made Islamic law "imprisoned".

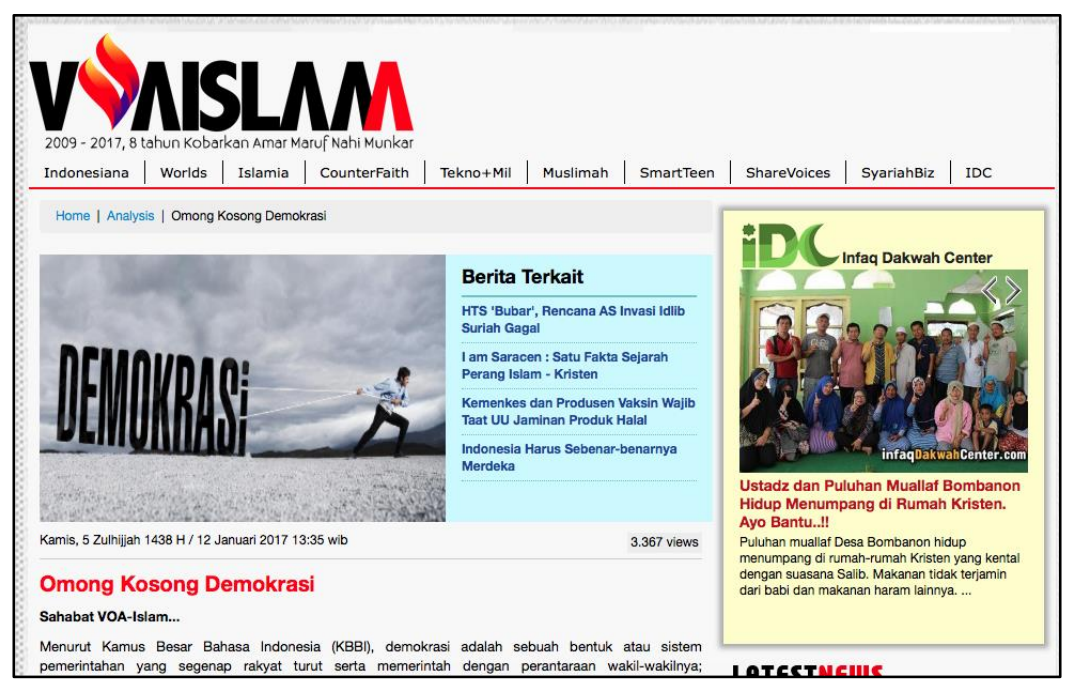

Picture 1. Display sample of VOA-Islam.com website

Then, there is also editorial opinion article entitled "Demokrasi Tak Ramah Syariat Islam" (20/01/17). The VOA-Islam editorial staff argued that from time to time democracy continues to destroy the purity of Islamic jihad and suppress the voices of Moslems. This article also emphasized that Moslems will always face enemies which in this case means "liberal, secular, pluralistic, and heretical figures under the guise of diversity and democracy" and "foreign compradors" and "aseng", where foreign here can be interpreted to refer to the other countries, especially Western countries, and aseng is the ethnic Chinese people who are often blamed as the party that controls the economy of the state of Indonesia. In this narration again the idea of democracy is directly confronted to the Islamic law, and the narration "We and They" is used to separate Islamic society from non-Moslem societies. This narration is certainly dangerous and potentially cause hostility in the life of Indonesian society consisting of various tribes and religions.

Another article related to democracy can be seen in the article of Wijaya Kurnia Santoso who mentions that he is "Syabab HTI Nganjuk" entitled "Mahalnya Memilih Pemimpin dalam Sistem Demokrasi," (06/03/17) VOA-Islam discusses how the election that is part of the democratic process in Indonesia is very expensive and provides opportunities for corruption. Some data on the cost of simultaneous elections as part of the democratic process are presented under the assumption that the expensive costs are vulnerable to misappropriation and potentially to be corrupted. Then this writing is closed with the call that it is natural that democracy is a failed, corrupt and costly system because democracy is the result of human thought that must be "abandoned and dumped" immediately and call upon Moslems to "return" to the Islamic law.

It is interesting to note that quite a lot of articles in VOA-Islam discuss about the 2017 election of Jakarta like the two articles that have been described previously and many other articles such as the article entitled "Demokrasi biang Perpecahan dalam memilih Pemimpin Muslim" (19/03/17) and "Pesta Demokrasi telah usai, What's Next?" (03/05/17). 
VOA-Islam often emphasizes explicitly on the negative impacts of democracy in Indonesia, for example, the emphasis that democracy is fail, destructive and costly system. In addition to providing the explanation that democracy is expensive, VOAIslam states that democracy has failed to eliminate political oligarchy. The oligarchy allows authority belongs only to minority capitalists, political classes and the elites of party. VOA-Islam alleges that the leader of political party, the majority today is a wealthy ruler. Politicians play with two faces, playing with power while accumulating wealth.

Next, a similar perspective on democracy can also be found in the news contained in ArRahmah website. One of the articles from ArRahmah site for example, entitled "Masalahnya adalah demokrasi itu sendiri" (11/04/2017), which shows how they frame democracy as a corrupt system. In addition to promote secularism, democracy also makes social gaps wider. They argue that this system tends to oppress the poor. In democracy, wealth is only for those who have access to power. This article is written quite well compared to the other writings because it uses some data taken from several sources such as Republika, which also refers to the writing of Nanat Fatah Natsir, Former Presidium of ICMI Central, and Former Rector of UIN Sunan Gunung Djati Bandung, or from economist Faisal Basri. But unfortunately the data and sources used are not written completely and like other writings, the arguments conveyed are still strong with nuances of blaming democracy from one side.

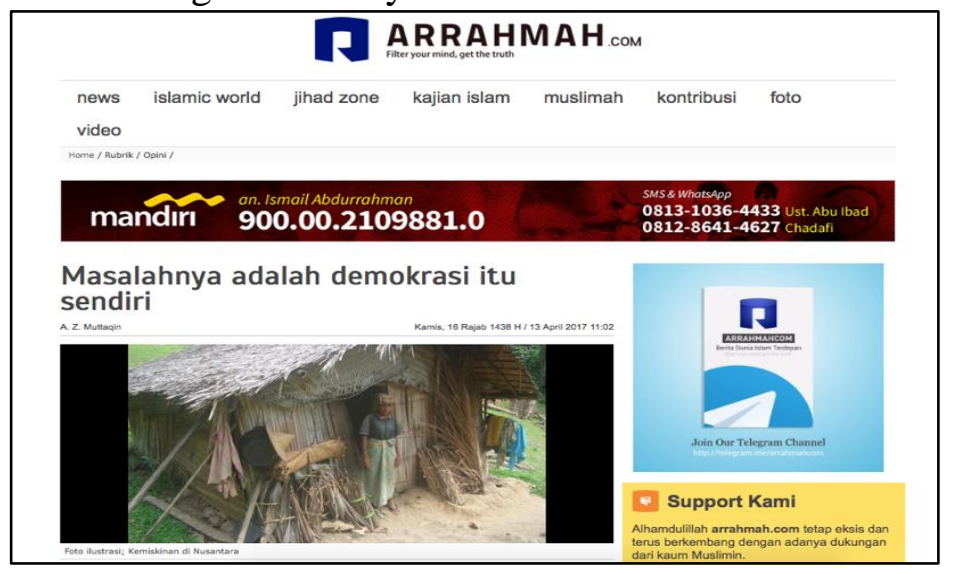

Picture 2. Display sample of ArRahmah.com site

Another article on democracy entitled "Demokrasi Myanmar menunjukkan kebencian yang mendalam" (16/02/2017). This article clearly states that democracy, especially in Myanmar, is a system that shows deep hatred for Rohingya's ethnic as a minority Moslem community. This article represents an understanding on democracy according to the ideology of Islamism followers as source of problems that society should avoid because of its negative impact on humanity. The author of this article also says that democracy is a "toxic" system and its antidote is the Islamic law.

The representation of democracy as a source of trouble can also be seen in another article entitled, "Terkait Arab Spring, Direktur CIA sebut AS terlalu ingin memaksakan demokrasi di negara-negara Arab" (20/10/2017). Democracy has been blamed for the existing conflict and instability of countries in Tunisia, Egypt, Bahrain and other Middle East regions. This article quotes $\mathrm{CNN}$ as the main source of news and focuses on the role of democracy as the main cause of political instability in the Arab countries without including other analyzes related to situation and condition in the region. Arab Spring itself has become topic widely discussed in various studies and perspectives. Using the ideology of democracy as the main cause is disregarding various actual political 
situations and conditions, and also the role of the hard-line Islamic groups from different ideologies that want to rule.

The two articles mentioned above are interesting because ArRahmah seeks to frame democracy as a troubled concept in countries other than Indonesia. The choosing of Myanmar with its Rohingnya and Arab Spring is certainly also done to establish the impression that the suffering experienced by Moslems in these two areas is directly caused by democracy.

\section{Conclusion}

This study tries to analyze how VOA-Islam and ArRahmah, for examples of Islamic news site in Indonesia, describe democracy as a bad, negative concept, not beneficial to Indonesian citizens, and contrary to Islamic law while emphasizing the importance of the application of Islamic law in Indonesia. Through the analysis result, it can be seen clearly that VOA-Islam and ArRahmah openly reject the idea that Indonesia is a secular-democratic country. In their articles, they often use the Arabic term derived from the Qur'an as legitimation of their arguments. The two sites we studied consistently created the illusion of "crime" of democracy by always labelling negatively. This association is useful as persuasion tool that creates "moral perspective on life" and "activates an unconscious emotional association" (Bhatia, 2009: 280).

By appointing these labels, they try to build the idea of democracy with emotional and frightening imagery associated with things that are considered haram (prohibited) or condemned in Islam. Throughout our analysis, the idea of the Islamic law as substitute for democracy is also continuously echoed. This analysis also points to the proximity of the ideological positions of VOA-Islam and ArRahmah with the general notion of Islamism that;

"... The political understanding on Islamism centers on the code of alternative law, shari'a ... Islamism and the implementation of shari'a are about religious belief, but it also [considered] respects the rule of law and human rights ... Shari'a followers [believe] that it offers security for Moslems against the dictatorial tyranny ... " (Azzam, 2006: 1130).

Democracy is certainly not a flawless system of government. In the long history of Indonesia, this country has also experienced several changes of governmental system and also entered the Reformation era after being in an authoritarian regime. Ideology and political ideas about Islam have also colored the various joints of political life in Indonesia. But of course it would be a problem if Islamic news sites like VOA-Islam and ArRahmah offer a very unilateral viewpoint and narrative as well as always give negative nuance about democracy. Moreover, some of the criticisms built by these sites do not lead to the potential for healthy and productive discussions for mutual progress. The way of the preaching and the worldviews constructed are feared will further divide the community into "we oppose them" sentiment, where "We" here are broadly generalized as Moslems, and "they" are the parties who defend the ideas of democracy.

Indonesia is vast archipelago and culturally diverse. In this diversity there must be different ideologies and views or political movements. It takes maturity to engage in healthy dialogue without subsequently maligning one another without clear foundation. Associated with Islam, of course, various ways of looking at the position of Islam in Indonesia are needed. Islamic news sites with more enlightening, logical, and scientific perspective are more needed as alternative readings for Moslems. The study of Islam as ideology and political movement in Indonesia today has been the concern of many

Jurnal The Messenger, Vol. 10, No. 1, January 2018, pp. 14-23 
academics. This paper only sees two Islamic news sites, and therefore the results can not be generalized in seeing various other Islamic news sites in Indonesia. Further research can be done by taking larger research samples and using another method such as quantitative content analysis to see the views related to the concept of democracy from various Islamic news sites in Indonesia more broadly.

\section{Acknowledgement}

The writers are grateful to the colleagues at the Faculty of Communication Sciences (Universitas Padjadjaran) for the support given in the process of writing this article.

\section{References}

Abba, G. (2015, 47). Retrieved from Kompas.com, http://nasional.kompas.com/read/2015/04/07/18333321/Pemilik.Arrahmah.com.K onten.Kami.Terkait.Perjuangan.Islam.tetapi.Tidak.Radikal

Adhitama, P.A. (2016). Analisis Framing Pembentukan Citra Soemarmo Hadi Saputro Menjelang Pemilihan Walikota Semarang tahun 2015 di Media Harian Rakyat Jateng. Jurnal the Messenger, 8 (1), 27-35.

Alexa (n.d.). Alexa.com. Retrieved from http://www.alexa.com/

Aminuddin, T.A. (2017). Instagram: Bingkai Kasus Agama di Media Sosial. Jurnal the Messenger, 9 (2), 163-175.

Azzam, M. (2006). Islamism Revisited. International Affairs, 82 (6), 1119-1132.

Bamualim, C. S. (2011). Islamic Militancy and Resentment against Hadhramis in PostSuharto Indonesia: A Case Study of Habib Rizieq Syihab and His Islamic Defenders Front. Comparative Studies of South Asia, Africa and The Middle East, 31 (2), 267-281.

Bhatia, A. (2009). The discourses of terrorism. Journal of Pragmatics, 41 (2), 279-289.

Brown, M. (2010). Representations of Islamic fundamentalism and the Ahmed Zaoui case. Islam and Christian-Muslim Relations, 21 (4), 331-341.

Budiasa, M. (2017). Mediatisasi Aksi Massa Islam 2 Desember 2016. Jurnal Komunikasi Profetik, 10 (1), 35-49.

Bunt, G. R. (2006). Towards an Islamic Information Revolution? In E. Poole, \& E. J. Richardson (Eds.), Muslims and the News Media. London: I.B. Tauris.

Eriyanto. (2012). Analisis Framing (Konstruksi, Ideologi, dan Politik Media). Yogyakarta: Lkis.

Fairclough, N. (1989). Language and Power. London: Longman.

Fowler, R. (1991). Language in the News. London and NewYork: Routledge.

Hartawan, T. (2012). Tempo.co. Retrieved from https://m.tempo.co/read/news/2012/02/18/063384813/fpi-anggap-mediapendorong-citra-negatif\#8uOsPeGf5LCyFczw.97

Hui, Y. J. (2010). The Internet in Indonesia: Development and Impact of Radical Websites. Studies in Conflict \& Terrorism, 33 (2), 171-191.

Human Rights Watch. (2013). In Religion's Name. NewYork: Human Rights Watch.

Iqbal, M. A. (2017). researchrepository.murdoch.edu. Retrieved from http://researchrepository.murdoch.edu.au/id/eprint/36066/1/iqbal2017.pdf

Kami, M. I. (2017, Mei 09). news.detik.com. Retrieved from detik.com: https://news.detik.com/berita/3495942/putusan-sidang-penistaan-agama-danrangkaian-aksi-bela-islam 
MacDonald, M. (2003). Exploring Media Discourse. London: Hodder and Straughton.

Matheson, D. (2005). Media Discourses: Analysing Media Texts. Berkshire: Open University Press.

Mujani, S. R., \&Liddle, W. (2009). Muslim Indonesia's Secular Democracy. Asian Survey, 49 (4), 575-590.

Nawab, M., \& Osman, M. (2010). Reviving the Caliphate in the Nusantara: Hizbut Tahrir Indonesia's Mobilization Strategy and Its Impact in Indonesia. Terrorism and Political Violence, 22 (4), 601-622.

Prihadi, D. S. (2017, Januari 3). Retrieved from cnnindonesia.com: https://www.cnnindonesia.com/teknologi/20170103101914-185-183699/kominfoblokir-voa-islam-dan-10-situs-sara-lainnya

Roberts, G. (2013). ABC News. Retrieved from http://www.abc.net.au/news/2013-0608/islamists-threaten-to-shut-down-indonesian-beauty-pageant/4741714

The Daily Star. (2013). The Daily Star Lebanon. Retrieved from http://www.dailystar.com.lb/News/International/2013/Feb-14/206427-indonesiaconservatives-protest-against-valentines-day.ashx\#axzz2Vk7dJhxa

The Telegraph. (2013). The Telegraph. Retrieved from http://www.telegraph.co.uk/news/worldnews/asia/indonesia/9870906/Islamicradicals-protest-sexy-Valentines-Day-in-Indonesia.html

Tibi, B. (2016). Islam dan Islamisme. Bandung: Mizan Pustaka.

Tonkiss, F. (2006). Analysing text and speech: content and discourse analysis. InC. Seale (Ed.), Researching Society and Culture. London: Sage.

Vollmer, C. (2017). 2017 Entertainment and Media Trends. Retrieved from strategyand.pwc.com, https://www.strategyand.pwc.com/trend/2017entertainment-and-media-trends

We Are Social. (2017, January 24). Retrieved from wearesocial.com: http://wearesocial.com/blog/2017/01/digital-in-2017-global-overview

Whine, M. (1999). Islamist Organizations on the Internet. Terrorism and Political Violence, 11 (1), 123-132.

Yusuf, O. (2016, 06 16). Retrieved from Tekno.Kompas.Com, http://tekno.kompas.com/read/2016/06/16/14341867/jibriel.tegaskan.arrahmah.bu kan.situs.radikal.dan.ia.bukan.tersangka

https://www.arrahmah.com/2017/02/16/demokrasi-myanmar-menunjukkan-kebencianyang-mendalam/

https://www.arrahmah.com/masalahnya-adalah-demokrasi-itu-sendiri/

https://www.arrahmah.com/2017/01/10/terkait-arab-spring-direktur-cia-sebut-as-terlaluingin-memaksakan-demokrasi-di-negara-negara-arab/

http://www.voa-islam.com/read/citizens-jurnalism/2017/03/19/49514/demokrasi-biangperpecahan-dalam-memilih-pemimpin-muslim/\#sthash.z7In5TX0.dpbs

http://www.voa-islam.com/read/opini/2017/04/20/50132/demokrasi-tak-ramah-syariatislam/\#sthash.x90qwzNQ.dpbs

http://www.voa-islam.com/read/citizens-jurnalism/2017/03/06/49260/mahalnyamemilih-peminpin-dalam-sistem-demokrasi/\#sthash.ixY3YBN1.dpbs

http://www.voa-islam.com/read/world-analysis/2017/01/12/48345/omong-kosongdemokrasi/\#sthash.JB07gWLq.dpbs

http://www.voa-islam.com/read/world-analysis/2017/05/03/50407/pesta-demokrasitelah-usai-whats-next/\#sthash.T5OHpIe8.dpbs 